\title{
Forthcoming Articles
}

The following is a list of Behavior Research Methods, Instruments, \& Computers articles that are currently in press. They are given in approximate order of acceptance. Each entry includes the initials (in parentheses) and address of the author with whom to communicate for further prepublication information. The author's e-mail address is also listed, if available.

Auto-Barona: An automated method of calculating premorbid IQ based on actuarial information. D. DORFMAN, J.F. KINCAID, \& J. WAKEMAN-

(D.D.) c/o Robert Proctor, 1364 Psychol. Sciences Bldg., Purdue Univ., West Lafayette, IN 47907-1364; dorfman@msvax.mssm.edu

Measures of effect size.

J.T.E. RICHARDSON-

(J.T.E.R.) Dept. of Human Sciences, Brunel Univ., Uxbridge, Middlesex UB8 3PH, England;

john.richardson@brunel.ac.uk

A new method of monitoring motor activity in baboons.

C.H. MAY, H.C. SING, R. CEPHUS, S. VOGEL, E.K. SHAYA, \& H.N. WAGNER-

(C.H.M.) Dept. of Neurosurgery, Humboldt-Univ., Bereich Medizin (Charité), Schumannstr, 20/21, 10117 Berlin, Germany

Pupillometry system for use in social psychology.

P.C. BERNHARDT, J.M. DABBS, JR., \& J.K. RIAD-

(P.C.B.) Dept. of Psychology, SBS 502, Univ. of Utah, Salt Lake City, UT 84112; pcbern@freud.sbs.utah.edu

GPOWER: A general power analysis program.

E. ERDFELDER, F. FAUL, \& A. BUCHNER-

(E.E.) Psychologisches Institut der Universität Bonn, Römerstrasse 164, D-53117 Bonn, Germany;

erdfelder@uni-bonn.de

Complete norms collected from young through elderly adults fór 198 sentence contexts.

M. J. HAMBERGER, D. FRIEDMAN, \& J. ROSEN - .

(M.J.H.) The Neurological Institute, Columbia Presbyterian Medical Center, 710 West 168th Street, New York, NY 10032; mh61@columbia.edu

Using Strawberry Tree WorkbenchMac and Workbench PC software for data acquisition and control in the animal learning laboratory.

I. MCGREGOR-

(I.M.) Department of Psychology, University of Sydney, NSW 2006, Australia; iain@psychvax.psych.su.oz.au

Fourier analysis of movement patterns in pigeons.

F. J. SILVA, J. J. PEAR, R. W. TAIT, \& J. J. FOREST-

(F.J.S.) Department of Psychology, Indiana University, Bloomington, IN 47405; fsilva@ucs.indiana.edu

A vocal response time system for use with sentence verification tasks.

C. JAMES-

(C.J.) Hearing Health Care Research Unit, Department of Communicative Disorders, University of Western Ontario, London, ON, Canada N6G $1 \mathrm{H} 1$

A Turbo Pascal program for the computation of scale-dependent association coefficients.

S. DECOENE-

(S.D.) Centrum voor Mathematische Psychologie en Psychologische Methodologie, Tiensestraat 102, 3000

Leuven, Belgium; fpaag08@blekul11.bitnet

A multistimulus, portable, and progammable conditioning panel for pigeons.

L. XIA, J.D. DELIUS, \& M. SIEMANN-

(J.D.D.) Allgemeine Psychologie, Universität Konstanz, D-78434 Konstanz, Germany; sydeli@dknkurzl.bitnet

A computer-controlled administration of the matching familiar figures test.

A.O. HUMMEL-SCHLUGER \& J.S. BAER-

(A.O.H.) Dept. of Psychology, Mailstop: JF-18, Univ. of Washington, Seattle, WA 98105;

ahummel@u.washington.edu 
Spider phobia control.

P. WHITBY-

(P.W.) Dept. of Psychology, Springfield Day Unit, St Wollos Hospital, Newport NP9 4SZ, England

Automated calculation of diagnostic efficiency statistics.

G.L. CANIVEZ \& M.W. WATKINS-

(G.L.C.) Dept. of Psychology, Eastern Illinois Univ., 400 Lincoln Ave., Charleston, IL 61920-3099

TESTAN_-An integrated modular system for personality assessment and test development on MSDOS PCs.

A. G. SHMELYOV--

(A.G.S.) ul.Hertzena 4, kom.24, "Human Technologies," Psychological Faculty of Moscow State University, 103009 Moscow, Russia; shmel@glas.apc.org

LEX I and II: Two databases of surface word forms for psycholinguistic research in Spanish.

J. SANTIAGO, F. JUSTICIA, A. PALMA, D. HUERTAS, \& N. GUTIERREZ-

(J.S.) Dept. Psicologia Experimental y Fisiologia del Comportamiento, Univ. of Granada, Granada 18001, Spain; jsantiago@ugr.es

Familiarity and relatedness of word meanings: Ratings for 110 homographs.

T. AZUMA-

(T.A.) Cognitive Systems Group, Psychology, Box 871104, Arizona State Univ., Tempe, AZ 85287-1104; astxa@asuacad

Lexical development norms for young children.

P.S. DALE \& L. FENSON-

(P.S.D.) Dept. of Psychology NI-25, Univ. of Washington, Seattle, WA 98195; pdale@u.washington.edu

An automated bisection device for assessing attentional neglect in clinical populations.

F.H. PREVIC--

(F.H.P.) AL/CFTF, 2504 Gillingham Dr., Ste. 1, Brooks AFB, TX 78235-5104;

previc\%kirk.decnet@hqhsd.brooks.af.mil

Computer simulations of the Rescorla-Wagner and Pearce-Hall models in conditioning and contingency judgment.

P. MERCIER -

(P.M.) School of Psychology, Univ. of Ottawa, Ottawa, ON, Canada K1N 6N5; nitch@acadvml.uottawa.ca

VTLOGANL: Coding and analyzing videotaped data.

J.B. HECHT \& N.K. ROBERTS-

(J.B.H.) TIER Lab., College of Education, Illinois State Univ., Normal, IL 61790-5900 ; jbhecht@ilstu.edu

Are inductively derived categories of facial activity reliable when applied to high-risk infants tested before term age?

T.E. HANNAN \& A.E. MOLITOR-

(T.E.H.) Dept. of Psychology, P.O. Box 90539, Duke Univ., Durham, NC 27708-0539;

thannan@acpub.duke.edu

RTSYS: A DOS application for the analysis of reaction time data.

A. HEATHCOTE-

(A.H.) Dept. of Psychology, Univ. of Newcastle, University Dr., Newcastle, NSW 2308, Australia; andrew@baal.newcastle.edu.au

An improved technique for creating hemifacial chimeras:

R. KOWNER-

(R.K.) Ctr. for East Asian Studies, Stanford Univ., 300 Lausen St., Stanford, CA 94305-5013 ub.duke.edu; rotem@human.tsukuba.ac.jp

H-Comp: A program to calculate information complexity.

M.E. NIELSEN--

(M.E.N.) Dept. of Psychology, Georgia Southern Univ., Landrum Box 8041, Statesboro, GA 30460-8041;

mnielsen@gasou.edu

Multimedia environmental decision making simulation.

C. SUMMERS-

(C.S.) Decision Research Group \& Dept. of Psychology, Laurentian Univ., Ramsey Lake Rd., Sudbury, ON, Canada P3E 2C6; csummers@nickel.laurentian.ca

Signal processing software for teaching and research in psychoacoustics under UNIX and X-Windows. J.F. CULLING-

(J.F.C.) MRC Institute of Hearing Research, University Park, Nottingham NG7 2RD, England;

johncu@ihr.mrc.ac.uk 
The phi maze: A versatile automated $T$ maze for learning and memory experiments in the rat. W.J. WILSON-

(W.J.W.) Dept. of Psychological Sci., Indiana-Purdue Univ. Fort Wayne, 2101 Coliseum Blvd. East, Fort Wayne, IN 46805; wilsonj@smtplink.ipfw.indiana.edu

An apparatus for the assessment of prepulse inhibition in the frog.

H.S. HOFFMAN \& F. RUPPEN-

(H.S.H.) Dept. of Psychology, Dalton Hall, Bryn Mawr College, Bryn Mawr, PA 19010;

hhoffmam@cc.brynmawr.edu

Visual dissociation of digitized photographs.

P.J. BISHOP \& H. INTRAUB-

(H.I.) Dept. of Psychology, 220 Wolf Hall, Univ. of Delaware, Newark, DE 19716-2571;

intraub@strauss.udel.edu

Scoring options for recall tests (SORT): A BASIC program for entry and analysis of recall test data.

C.J. ELIE, J.M. BLACKWELL, \& D.G. PAYNE-

(D.G.P.) Dept. of Psychology, State University of New York., Binghamton, NY 13902;

dpayne@bingvmb.cc.binghamton.edu

An SPSS program to compute subjective organization.

J.K. KAZEN \& H. OTANI-

(H.O.) Dept. of Psychology, Central Michigan Univ., Mt. Pleasant, MI 48859; hajime.otani.cmich.edu

An optical encoder and XY oscilloscope interface for the IBM PC.

P. NAGELKERKE \& I.M. FRANKS-

(P.N.) School of Human Kinetics, 210-6081 University Blvd., Univ. of British Columbia, Vancouver, BC,

Canada V6T1Z1; pauln@unixg.ubc.ca

Detecting group differences in sequential association using sampled permutations: Log odds, kappa, and phi compared.

R. BAKEMAN, D. MCARTHUR, K. BALDWIN, \& V. QUERA-

(R.B.) Dept. of Psychology, Georgia State Univ., Atlanta, GA 30303-3083; psyrab@gsusgi2.gsu.edu

Content analysis in negotiation research: $A$ review and guide.

K.L. HARRIS

(K.L.H.) Dept. of Psychology, Western Illinois Univ., Macomb, IL 61455; harrisk@ccmail.wit.bgu.edu

Fully proportional actigraphy: A new instrument.

W.W. TRYON \& R. WILLIAMS-

(W.W.T.) Dept. of Psychology, Fordham Univ., Bronx, NY 10458-5198; wtryon@murray.fordham.edu

An injection olfactometer for humans and a new method for the measurement of the shape of the olfactory pulse.

R.A. DE WIJK, W. VAESSEN, J. HEIDEMA, \& E.P. KOSTER-

(R.A.D.) Brown \& Williamson Tobacco Co. (R\&D), 2600 Weaver Rd., Macon, GA 31298-1799; renedewijk@aol.com

Team-Track: A tool for investigating tracking performance in teams.

F. JENTSCH, C. BOWERS, D. COMPTON, G. NAVARRO, \& T. TAIT -

(F.J.) Team Performance Lab., Dept. of Psychology, Univ. of Central Florida, Orlando, FL 32816-1390; fj3539@pegasus.cc.ucf.edu

Programming without programming: The system Butterfly for professional psychologists.

B.V. PULKIN-

(B.V.P.) Institute of Psychology, Russian Academy of Sciences, 13 Yaroslavskaya St., 129366 Moscow, Russia; bpul@pras.msk.su

Naming times for the Snodgrass and Vanderwart pictures.

J.G. SNODGRASS \& T. YUDITSKY-

(J.G.S.) Dept. of Psychology, New York Univ., 6 Washington Pl., Rm. 857, New York, NY 10003 ;

gay@xp.psych.nyu.edu

Permustat: A Macintosh program for approximate randomization tests.

A.F. HAYES-

(A.F.H.) c/o Robert W. Proctor, Psychology, 1364 Psych. BIdg., Purdue Univ., West Lafayette, IN 47907-1364; afh3@cornell.edu

VIAT: A Windows program for demonstrating visual-attention effects,

R. HUBNER-

(R.H.) c/o Robert W. Proctor, Psychology, 1364 Psych. Bldg., Purdue Univ., West Lafayette, IN 47907-1364;

r.huebner@tu-bs.de 
A set of 254 Snodgrass-Vanderwart pictures standardized for Spanish: Norms for name agreement, image agreement, familiarity, and visual complexity.

M.C. SANFELIU \& A. FERNANDEZ-

(M.C.S.) Dept. di Psicologia Basica, Univ. de Salamanca, Avda. de la Merced, 109-131, 37005 Salamanca,

Spain; mcsanfe@gugu.usal.es

Investigating the human-computer interface using the Datalogger.

S.J. WESTERMAN, S. HAMBLY, C. ALDER, C.W. WYATT-MILLINGTON, C.M. CRAWSHAW, G.R. J.

HOCKEY, \& N.M. SHRYANE-

(S.J.W.) Dept. of Psychology, Univ. of Hull, Hull HU6 7RT, England; s.j.westerman@psy.hull.ac.uk

A simple Windows program for coding fast-changing events in observational situations divided into variable intervals.

T. RUUSUVIRTA, T. KORHONEN, \& J. ARIKOSKI-

(T.R.) c/o Robert W. Proctor Psychology, 1364 Psych. Bldg., Purdue Univ., West Lafayette, IN 47907-1364

Simple algorithms for creating random-element stereograms on the Macintosh.

J.A. BARO-

(J.A.B.) NASA Classroom of the Future, Wheeling Jesuit College, Wheeling, WV 26003; jabaro@cotf.edu

EthoLog 1.0-ethological transcription tool for Windows.

E.B. OTTONI-

(E.B.O.) c/o Robert W. Proctor, Psychology, 1364 Psych. Bldg., Purdue Univ., West Lafayette, IN 47907-1364;

ebottoni@usp.br

Utilizing the Sound Blaster 16 board for dichotic listening studies.

R.E. GRAVES \& T. ALLEN-

(R.E.G.) c/o Robert W. Proctor, Psychology, 1364 Psych. Bldg., Purdue Univ., West Lafayette, IN 47907-1364; rgraves@sol.uvic.ca

Covariance structure analysis in experimental research: Comparing two word translation models.

J.G. VAN HELL, P. OOSTERVELD, \& A.M.B. DE GROOT-

(J.G.V.) Dept. of Psychology, Univ. of Amsterdam, Roetersstraat 15, 1018 WB Amsterdam, The Netherlands; pn_hell@macmail.psy.uva.nl

GRIDLAT: Toward a constructivist methodology to investigate brain lateralization.

K.W. SEWELL \& D.L. PIERCE-

(K.W.S.) Dept. of Psychology, Univ. of North Texas, Denton, TX 76203 